\title{
KUALITAS PELAYANAN PADA PERPUSTAKAAN DAERAH KOTA SALATIGA
}

\author{
Oleh \\ Elisa Irawati ${ }^{1)}$, Tri Widodo ${ }^{2)}$ \\ Dosen STIE AMA Salatiga
}

\begin{abstract}
This research was conducted to determine the quality of service at the regional library in Salatiga. Primary data was obtained by distributing questionnaires to respondents, namely visitors at the Salatiga city library. The population in this study were 295,860 visitors and the sample in this study were 100 respondents who were students of STIE AMA, IAIN and SWCU Salatiga. The analysis used included multiple linear regression analysis, $t$ test and $F$ test. Based on the results of data analysis, the results of the study can be explained as follows: validity and reliability test shows that the count of each item > r-table (0.1946) and the value of Cronbach's Alpha each research variable > 0.6 so that the research declared valid and reliable. While the results of service satisfaction testing in the Salatiga city library were proven by adjusted $R$ Square in this study of 0.385 , which means that $38.5 \%$ of the satisfaction variables can be explained by five independent variables tangible, empathetic, reliability, responsiveness and assurance. While the remaining $61.5 \%$ is explained by other reasons outside the model. Test $F$ obtained $F$ count 13,396 probability 0,000. because the probability $<0.05$, the regression model can be said that tangible, empathetic, reliability, responsiveness and assurance together have an effect on satisfaction. The t test shows that tangible and emphaty variables have a significance value of $<0.05$, therefore, the two independent variables do affect satisfaction while the variables reliability, responsiveness and assurance have a significant number $>0.05$. Therefore, the three variables actually do not affect satisfaction. The conclusions in this study are of the five variables tested to see whether giving satisfaction to visitors to the Salatiga city library, it turns out that only two variables that significantly influence the satisfaction variable, both are tangible and empathetic variables.
\end{abstract}

Kata kunci: Tangible, emphaty, reliability, responsiveness, assurance dan kepuasan konsumen

\section{PENDAHULUAN}

Pada era teknologi dan informasi yang modern seperti saat ini, kebutuhan masyarakat terhadap informasi dan media edukasi merupakan hal penting dan perlu didukung oleh fasilitas - fasilitas yang lengkap dan modern sesuai dengan perkembangan jaman. Hal ini tentunya menjadi tantangan tersendiri bagi penyedia jasa informasi dan edukasi yang ada di Indonesia. Begitu juga program belajar gratis 12 tahun yang dicanangkan oleh pemerintah perlu didukung dengan fasilitas - fasilitas, 
salah satunya adalah buku. Buku yang merupakan jendela dunia bisa memberikan informasi dan ilmu pengetahuan yang luas kepada pembacanya.

Biaya produksi pembuatan buku yang tinggi membuat harga buku menjadi susah dijangkau oleh masyarakat. Pemerintah sebagai penyedia fasilitas bagi masyarakat mulai berpikir bagaimana agar masyarakat yang kesulitan untuk membeli buku tetap bisa membaca buku. Solusinya adalah pemerintah menyediakan sarana umum yang bermanfaat bagi masyarakat yang ingin membaca tapi kesulitan membelinya yaitu perpustakaan

Perpustakaan merupakan suatu tempat yang berisi buku - buku koleksi yang diatur dan disusun sedemikian rupa sehingga mudah untuk dicari dan dipergunakan apabila sewaktu-waktu diperlukan oleh pembaca (Sutarno NS, 2006:11). Di dalam perpustakaan tersebut setiap orang akan dapat mengakses semua informasi dan pengetahuan dalam format apapun.

Adanya perpustakaan diharapkan juga bisa meningkatkan minat baca masyarakat Indonesia yang masih kecil yaitu $0,01 \%$. Inilah yang mendorong pemerintah daerah untuk bisa membuat perpustakaan di daerahnya masing-masing tidak terkecuali Salatiga, sesuai dengan tujuan berdirinya perpustakaan adalah untuk menyediakan fasilitas dan sumber informasi dan menjadi pusat pembelajaran (Sutarno,2006:34).

Penciptaan suasana yang nyaman dan aman harus dipikirkan ketika akan mendirikan sebuah perpustakaan. Ini karena kualitas pelayanan yang baik dapat membuat konsumen mau berkunjung lagi dan dari hubungan tersebut pengelola dapat mengidentifikasi keinginanan dan kebutuhan konsumen sehingga pengelola dapat meningkatkan hal - hal yang dapat membuat konsumen senang atau puas terhadap pelayanan yang di berikan. Kualitas harus di mulai dari kebutuhan pelanggan dan berakhir pada persepsi pelanggan. Ini berarti bahwa citra kualitas yang baik tidak berdasarkan persepsi penyedia jasa, akan tetapi berdasarkan persepsi pelanggan.

Salah satu unit jasa yang ada di Salatiga adalah jasa perpustakaan. Kebutuhan konsumen khususnya mahasiswa terhadap ilmu pengetahuan dan media edukasi lainnya merupakan hal yang sulit untuk dipisahkan. Hampir semua insan akademik membutuhkan jasa perpustakaan untuk menunjang aktivitasnya, sehingga sarana 
perpustakaan memang sangat di butuhkan. Perpustakaan umum kota Salatiga mempunyai harapan besar agar perpustakaan dapat menjadi pusat informasi dan edukasi bagi mahasiswa. Berdasarkan uraian latar belakang diatas maka rumusan permasalahan penelitian ini adalah : apakah terdapat pengaruh dimensi kualitas pelayanan terhadap kepuasan mahasiswa pengguna perpustakaan daerah kota salatiga ? Tujuan dari suatu penelitian adalah menjawab persoalan penelitian yang diangkat, dalam penelitian ini tujuannya adalah sebagai berikut : Untuk mengetahui pengaruh dimensi kualitas pelayanan terhadap kepuasan mahasiswa pengunjung perpustakaan daerah kota salatiga

\section{KAJIAN TEORITIS}

Berkaitan dengan penelitian ini, maka peneliti membutuhkan konsep yang akan dipergunakan sebagai dasar penelitiannya.

\section{Kualitas Pelayanan}

Tjiptono ( dikutip oleh Naryawan, 2011 ) menyatakan bahwa kualitas pelayanan jasa adalah tingkat keunggulan yang diharapkan dan pengendalian atas tingkat keunggulan tersebut untuk memenuhi keinginan pelanggan. Pengertian menurut Kotler (2000:25), kualitas pelayanan merupakan totalitas dari bentuk karakteristik barang dan jasa yang menunjukkan kemampuannya untuk memuaskan kebutuhan pelanggan, baik yang nampak jelas maupun yang tersembunyi. Bagi perusahaan yang bergerak di sektor jasa, pemberian pelayanan yang berkualitas pada pelanggan merupakan hak mutlak yang harus dilakukan apabila perusahaan ingin mencapai keberhasilan.

\section{Kepuasan Konsumen}

Ada beberapa definisi terkait dengan kepuasan konsumen diantaranya adalah Kotler (2001:46) yang menekankan bahwa kepuasan konsumen merupakan tingkat perasaan seseorang setelah membandingkan kinerja (atau hasil) yang ia rasakan dengan harapannya. Bila kinerja melebihi harapan maka mereka akan puas dan sebaliknya jika kinerja tidak sesuai harapan makan akan kecewa. Sedangkan definisi lain menyatakan kepuasan konsumen merupakan suatu dorongan keinginan individu yang diarahkan pada tujuan untuk memperoleh kepuasan. 


\section{HIPOTESIS}

1. $\mathrm{H}_{1}$ : Terdapat pengaruh tangible terhadap kepuasan konsumen

2. $\mathrm{H}_{2}$ : Terdapat pengaruh empathy terhadap kepuasan konsumen

3. $\mathrm{H}_{3}$ : Terdapat pengaruh reliability terhadap kepuasan konsumen

4. $\mathrm{H}_{4}$ : Terdapat pengaruh responsiveness terhadap kepuasan konsumen

5. $\mathrm{H}_{5}$ : Terdapat pengaruh assurance terhadap kepuasan konsumen

\section{METODE PENELITIAN}

\section{Definisi Operasional}

Definisi operasional adalah aspek penelitian yang memberikan informasi kepada kita tentang bagaimana caranya mengukur variabel.

\section{Variabel Penelitian}

a. Tangible ( bukti fisik )

Tangible diartikan sebagai penampilan fisik seperti peralatan, penampilan karyawan, fasilitas gedung dan lainnya.

b. $\quad$ Empathy (empati)

Empathy adalah perhatian secara individu yang diberikan oleh penyedia jasa sehingga pelanggan merasa penting, dihargai dan dimengerti oleh perusahaan.

c. Reliability (kehandalan)

Reliability adalah kemampuan untuk memberikan jasa sesuai dengan yang dijanjikan dengan akurat dan handal.

d. Responsiveness (tanggapan)

Responsiveness adalah kesediaan untuk membantu pelanggan dan memberikan pelayanan dengan segera dan tepat. 
e. Assurance (jaminan)

Assurance adalah pengetahuan, keramahan serta kemampuan karyawan untuk menimbulkan kepercayaan pelanggan terhadap perusahaan.

\section{f. Kepuasan}

Kepuasan adalah perasaan senang atau kecewa seseorang yang berasal dari perbandingan antara kesannya terhadap kinerja suatu produk serta harapanharapannya akan produk tersebut.

\section{Populasi dan Sampel}

Adapun sampel penelitian ini adalah mahasiswa pengunjung perpustakaan daerah kota salatiga. Bila diketahui jumlah mahasiswa yang berkunjung ke perpustakaan daerah kota salatiga pada tahun 2017 adalah 295.860 pengunjung, maka berdasarkan perhitungan rumus slovin, maka jumlah sampel yang dapat digunakan pada penelitian ini adalah 99,97 atau dibulatkan menjadi 100 responden

\section{METODE ANALISIS DATA}

\section{a. Uji Validitas}

Uji validitas digunakan untuk mengukur sah atau valid tidaknya suatu kuisioner. Untuk menguji ketepatan kuisioner digunakan rumus koefisien korelasi metode product moment yang dikemukakan oleh Karl Pearson. Pengujian validitas pada taraf yang signifikan digunakan adalah $=5 \%$

\section{b. Uji Reliabilitas}

Untuk mengukur reliabilitas yaitu melalui uji cronbach alpha. Variabel akan dikatakan reliable apabila hasil (cronbach alpha) $>0,60$

\section{c. Uji Normalitas Data}

Model regresi yang baik adalah yang berdistribusi normal atau mendekati nol. Suatu data berdistribusi normal dilihat dari penyebarannya pada sumbu diagonal dari grafik.

\section{Uji Multikolinearitas}

Pengujian multikolinieritas dilakukan dengan melihat nilai tolerance dan lawannya. Suatu model regresi dikatakan bebas dari multikolinieritas jika nilai 
tolerance $<0,10$ atau sama dengan nilai VIF $>10$ (Ghozali,2006). Jika terjadi multikolinieritas maka dilakukan perbaikan dengan menghilangkan salah satu variabel independen dengan korelasi tertinggi

\section{Uji Heteroskedastisitas}

Jika ada pola tertentu, seperti titik yang ada membentuk pola tertentu yang teratur (bergelombang, melebar kemudian menyempit) maka mengindikasikan telah terjadi heteroskedastisitas (Ghozali,2006)

\section{Analisis Regresi Linier Berganda}

Penelitian ini menggunakan teknik analisis data yaitu regresi berganda untuk mengetahui pengaruh variabel dependen (X) terhadap variabel independen (Y). Untuk itu diformulasikan model berganda sebagai berikut : $\mathrm{Y}=\mathrm{a}+\mathrm{b}_{1} \mathrm{X}_{1}+$ $b_{2} X_{2}+b_{3} X_{3}+b_{4} X_{4}+b_{5} X_{5}+e$

\section{d. Uji Signifikan Pengaruh Parsial (Uji t)}

Uji $\mathrm{t}$ digunakan untuk menunjukkan seberapa jauh pengaruh satu variabel penjelas/independen secara individual dalam menerangkan variasi variabel dependen, dimana $\alpha=0,05$ (Ghozali, 2006)

\section{e. Uji Signifikan Simultan (Uji F)}

Uji $\mathrm{F}$ digunakan untuk menunjukkan seberapa jauh pengaruh satu variabel penjelas/independen secara serentak dalam menerangkan variasi variabel dependen, dimana $\alpha=0,05$ (Ghozali, 2006)

\section{f. Koefisien Determinasi $\left(\mathbf{R}^{2}\right)$}

Nilai $\mathbf{R}^{\mathbf{2}}$ yang kecil berarti kemampuan variabel-variabel independen dalam menjelaskan variabel dependen amat terbatas. Nilai yang mendekati 1 berarti variabel-variabel independen memberikan hampir semua informasi yang dibutuhkan untuk memprediksi variabel-variabel dependen (Ghozali,2005). 


\section{ANALISIS DAN PEMBAHASAN}

\section{Uji Reliabilitas}

Uji reliabilitas dimensi tangible menunjukkan 0,730>0,6 sehingga dapat dikatakan bahwa instrumen penelitian untuk variabel tangible reliabel. Uji reliabilitas emphaty menunjukkan 0,813 > 0,6 sehingga dapat dikatakan bahwa instrumen penelitian untuk variabel emphaty reliabel. Uji reliabilitas dimensi reliability menunjukkan 0,714 > 0,6 sehingga dapat dikatakan bahwa instrumen penelitian untuk variabel reliability reliabel. Uji reliabilitas responsiveness menunjukkan 0,754 > 0,6 sehingga dapat dikatakan bahwa instrumen penelitian untuk variabel responsive reliabel. Uji reliabilitas dimensi assurance menunjukkan 0,631 > 0,6 sehingga dapat dikatakan bahwa instrumen penelitian untuk variabel assurance reliabel. Uji reliabilitas variabel kepuasan pelanggan menunjukkan 0,796 > 0,6 sehingga dapat dikatakan bahwa instrumen penelitian untuk variabel kepuasan pelanggan reliabel.

\section{Uji Validitas}

Jika dilihat dari hasil corrected item to total correlation, maka dapat disimpulkan bahwa setiap item pertanyaan pada variabel tangible valid karena nilai korelasinya > dari rtabel nya yaitu 0,1946 . Jika dilihat dari hasil corrected item to total correlation, maka dapat disimpulkan bahwa setiap item pertanyaan pada variabel emphaty valid karena nilai korelasinya > dari r-tabel nya yaitu 0,1946 . Jika dilihat dari hasil corrected item to total correlation, maka dapat disimpulkan bahwa setiap item pertanyaan pada variabel reliability valid karena nilai korelasinya > dari r-tabel nya yaitu 0,1946. Jika dilihat dari hasil corrected item to total correlation, maka dapat disimpulkan bahwa setiap item pertanyaan pada variabel responsive valid karena nilai korelasinya > dari r-tabel nya yaitu 0,1946. Jika dilihat dari hasil corrected item to total correlation, maka dapat disimpulkan bahwa setiap item pertanyaan pada variabel assurance valid karena nilai korelasinya > dari r-tabel nya yaitu 0,1946 . Jika dilihat dari hasil corrected item to total correlation, maka dapat disimpulkan bahwa setiap item pertanyaan pada variabel kepuasan pelanggan valid karena nilai korelasinya > dari r-tabel nya yaitu 0,1946. 


\section{Uji Multikolinieritas}

Hasil perhitungan nilai tolerance menunjukkan tidak ada variabel independen yang memiliki nilai tolerance kurang dari 0,10 yang berarti tidak ada korelasi antar variabel independen yang nilainya lebih dari 95\%. Hasil perhitungan nilai VIF juga menunjukkan hal yang sama, tidak ada satupun variabel independen yang memiliki nilai VIF lebih dari 10. Jadi dapat disimpulkan bahwa tidak ada multikolinieritas antar variabel independen dalam model regresi.

\section{Uji Heteroskedastisitas}

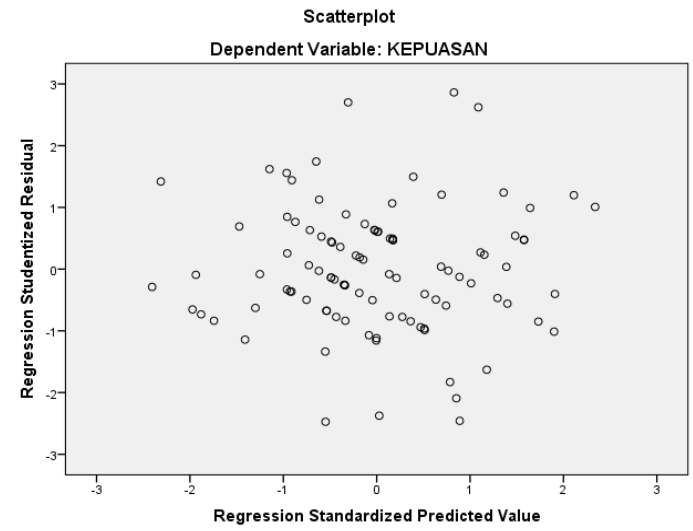

Dari grafik scatterplot terlihat bahwa titik-titik menyebar secara acak serta tersebar baik diatas maupun dibawah angka 0 pada sumbu Y. Jadi dapat disimpulkan bahwa tidak terjadi heteroskedastis pada model regresi, sehingga model regresi layak dipakai.

\section{Uji Normalitas}

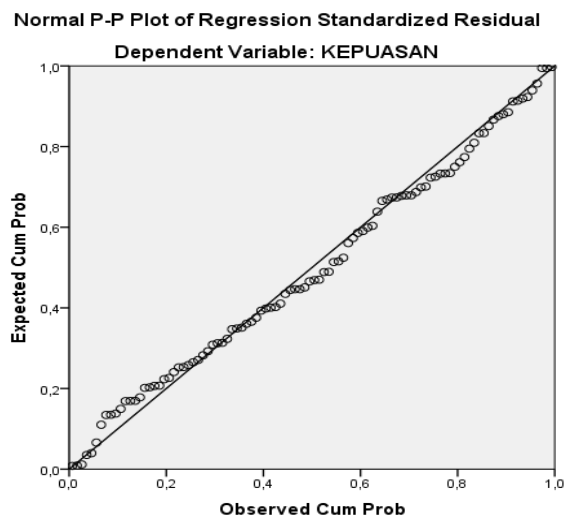




\section{Regresi Berganda}

\section{Koefisien determinasi}

Model Summary ${ }^{b}$

\begin{tabular}{|l|r|r|r|r|}
\hline $\begin{array}{l}\text { Mode } \\
1\end{array}$ & \multicolumn{1}{|c|}{$\mathrm{R}$} & $\mathrm{R}$ Square & $\begin{array}{c}\text { Adjusted R } \\
\text { Square }\end{array}$ & $\begin{array}{r}\text { Std. Error of } \\
\text { the Estimate }\end{array}$ \\
\hline 1 &, $645^{\mathrm{a}}$ &, 416 &, 385 & 1,75114 \\
\hline
\end{tabular}

a. Predictors: (Constant), ASSURANCE, RESPONSIVENESS, TANGIBLE, RELIABILITY, EMPHATY

b. Dependent Variable: KEPUASAN

Adjusted R Square dalam penelitian ini sebesar 0,385 (lebih kecil dari R Square yaitu 0,416) artinya adalah 38,5\% variabel kepuasan dapat dijelaskan oleh lima variabel independen tangible, emphaty, reliability, responsiveness dan assurance. Sedangkan sisanya $(100 \%-38,5 \%=61,5 \%)$ dijelaskan oleh sebab-sebab lain diluar model.

\section{Uji F}

ANOVA $^{\mathrm{a}}$

\begin{tabular}{|rl|r|r|r|r|r|}
\hline \multicolumn{1}{|c|}{ Model } & & Sum of Squares & Df & Mean Square & F & Sig. \\
\hline \multirow{2}{*}{1} & Regression & 205,391 & 5 & 41,078 & 13,396 &, $000^{\mathrm{b}}$ \\
& Residual & 288,249 & 94 & 3,066 & & \\
& Total & 493,640 & 99 & & & \\
\hline
\end{tabular}

a. Dependent Variable: KEPUASAN

b. Predictors: (Constant), ASSURANCE, RESPONSIVENESS, TANGIBLE, RELIABILITY, EMPHATY

Dari uji ANOVA atau F test didapat nilai F hitung sebesar 13,396 dengan probabilitas 0.000. karena probabilitas jauh lebih kecil dari 0,05 maka model regresi dapat digunakan untuk memprediksi KEPUASAN atau dapat dikatakan bahwa tangible, emphaty, reliability, responsiveness dan assurance secara bersama-sama berpengaruh terhadap kepuasan 
Uji t

Coefficients $^{\mathrm{a}}$

\begin{tabular}{|c|c|c|c|c|c|c|c|c|}
\hline \multirow{2}{*}{\multicolumn{2}{|c|}{ Model }} & \multicolumn{2}{|c|}{$\begin{array}{c}\text { Unstandardized } \\
\text { Coefficients }\end{array}$} & \multirow{2}{*}{$\begin{array}{c}\begin{array}{c}\text { Standardized } \\
\text { Coefficients }\end{array} \\
\text { Beta }\end{array}$} & \multirow[t]{2}{*}{$\mathrm{T}$} & \multirow[t]{2}{*}{ Sig. } & \multicolumn{2}{|c|}{ Collinearity Statistics } \\
\hline & & B & Std. Error & & & & Tolerance & VIF \\
\hline \multirow{6}{*}{1} & (Constant) & 822 & 2,379 & & ,345 & ,731 & & \\
\hline & TANGIBLE & ,153 &, 065 &, 231 & 2,372 &, 020 & 657 & 1,522 \\
\hline & EMPHATY &, 164 &, 080 &, 224 & 2,038 &, 044 &, 514 & 1,944 \\
\hline & RELIABILITY & , 179 &, 104 &, 182 & 1,723 & ,088 &, 556 & 1,799 \\
\hline & RESPONSIVENESS & 087 & , 107 &, 074 & ,814 &, 418 &, 742 & 1,347 \\
\hline & ASSURANCE & 113 &, 100 &, 116 & 1,134 & ,260 &, 595 & 1,680 \\
\hline
\end{tabular}

a. Dependent Variable: KEPUASAN

Variabel tangible dan emphaty mempunyai angka significance dibawah 0.05. karena itu, kedua variabel independen tersebut memang mempengaruhi kepuasan. Variabel reliability, responsiveness dan assurance mempunyai angka signifikan diatas 0,05. Karena itu, ketiga variabel tersebut sebenarnya tidak mempengaruhi kepuasan.

\section{KESIMPULAN}

Kesimpulan akhir dari penelitian ini adalah dari lima variabel yang diuji untuk melihat apakah memberikan kepuasan kepada pengunjung perpustakaan daerah kota Salatiga, ternyata hanya dua variabel yang signifikan memberikan pengaruh pada variabel kepuasan, keduanyanya adalah variabel tangible dan emphaty.

Variabel tangible dan emphaty merupakan variabel yang berpengaruh kuat terhadap variabel kepuasan. Artinya kepuasan pengunjung di perpusda dipengaruhi oleh bukti fisik dan empati atau layanan. Keduanya secara signifikan memberikan pengaruh pada kepuasan pengunjung. 


\section{DAFTAR PUSTAKA}

Kotler, Phillip. 2001. Manajemen pemasaran di indonesia : analisis, perencanaan, implementasi, pengendalian. Salemba empat. Jakarta

Abdul Rahman Saleh, Erni Sumarni, Sri Rahayu Safitri, kajian "analisis kepuasan pelanggan pada layanan perpustakaan badan standaririsasi nasional". Jurnal Pustakawan Indonesia Volume 13 No. 2

Wijaya Satria, 2017. "analisis tingkat kepuasan mahasiswa terhadap pelayanan bagian keuangan dengan metode customer satisfaction index". Jurnal Ilmiah Rekayasa dan Manajemen Sistem Informasi, Vol. 3, No. 1, Februari 2017, Hal. 11-17

Barnes, James G. 2003. Secrets of Customer Relationship Management (Rahasia Manajemen Hubungan Pelanggan). Yogyakarta: Andi.

Lasa, 2005. Manajemen Perpustakaan. Yogyakarta: Gama Media.

Naryawan. 2011. Analisis pengaruh kualitas pelayanan terhadap kepuasan mahasiswa pengguna jasa perpustakaan referensi fe-undip

Ghozali, Imam. 2006. Aplikasi Analisis Multivariate Dengan Program IBM SPSS 21. Edisi 7. Semarang: Badan Penerbit Universitas Diponegoro.

Santoso, Singgih, dan Fandy Tjiptono, 2002, Riset Pemasaran : Konsep dan Aplikasinya dengan SPSS, Jakarta : PT Elex Media Computindo Kelompok Gramedia

Sutarno, NS. 2006. Manajemen perpustakaan

Kotler, Philip and Gary Armstrong. 2012. Prinsip-prinsipPemasaran. Edisi13. Jilid 1. Jakarta: Erlangga Kotler, Philip, 2000, Marketing Management. Edisi Milenium, Prentice Hall Intl,Inc.New Jersey. 